\title{
Herpetofauna of the Reserva Ecológica de Guapiaçu (REGUA) and its surrounding areas, in the state of Rio de Janeiro, Brazil
}

\author{
Mauricio Almeida-Gomes ${ }^{1,5}$, Carla Costa Siqueira ${ }^{2}$, Vitor Nelson Teixeira Borges-Júnior², \\ Davor Vrcibradic ${ }^{3}$, Luciana Ardenghi Fusinatto ${ }^{4}$ \& Carlos Frederico Duarte Rocha ${ }^{2}$ \\ ${ }^{1}$ Departamento de Ecologia, Universidade Federal do Rio de Janeiro, Avenida Carlos Chagas Filho, 373, \\ Cidade Universitária, CEP 21941-902, Rio de Janeiro, RJ, Brazil. \\ ${ }^{2}$ Departamento de Ecologia, Universidade do Estado do Rio de Janeiro, R. São Francisco Xavier 524, CEP \\ 20550-013, Rio de Janeiro, RJ, Brazil. \\ ${ }^{3}$ Departamento de Zoologia, Universidade Federal do Estado do Rio de Janeiro, Av. Pasteur 458, Urca, \\ CEP 22240-290, Rio de Janeiro, RJ, Brazil. \\ ${ }^{4}$ Departamento de Ciências Biológicas, Universidade Federal de São Paulo, Campus Diadema, Rua Prof. \\ Artur Ridel, 275, Eldorado, CEP 09972-270, Diadema, SP, Brazil. \\ ${ }^{5}$ Corresponding author: Mauricio Almeida-Gomes, e-mail: almeida.gomes@yahoo.com.br
}

ALMEIDA-GOMES, M., SIQUEIRA, C.C., BORGES-JÚNIOR, V.N.T., VRCIBRADIC, D., FUSINATTO, L.A., ROCHA, C.F.D. Herpetofauna of the Reserva Ecológica de Guapiaçu (REGUA) and its surrounding areas, in the state of Rio de Janeiro, Brazil. Biota Neotropica. 14(3): e20130078. http:// dx.doi.org/10.1590/1676-0603007813

\begin{abstract}
Species inventories are useful tools to improve conservation strategies, especially in highly threatened biomes such as the Brazilian Atlantic Forest. Here we present a species list of amphibians and reptiles for the Reserva Ecológica de Guapiaçu (REGUA), a forest reserve located in the central portion of Rio de Janeiro state, Brazil. The list results from an extensive sampling effort that lasted ten years. A total of 73 amphibian (of which ten are endemic to the state) and 37 reptile species was recorded from the area. Five amphibian species are presently categorized by the IUCN as "data-deficient", two as "near threatened" and one as "endangered", whereas one reptile species is categorized as "vulnerable". Our results showed that REGUA harbors about one-third of the herpetofauna species presently known to occur in state of Rio de Janeiro, adding more information to previously published lists of amphibians and reptiles from localities within the Serra dos Órgãos region, and highlighting the importance of this area for conservation of amphibians and reptiles of the Atlantic Forest.
\end{abstract}

Keywords: amphibians, Atlantic Forest, conservation, hotspot, reptiles.

ALMEIDA-GOMES, M., SIQUEIRA, C.C., BORGES-JÚNIOR, V.N.T., VRCIBRADIC, D., FUSINATTO, L.A., ROCHA, C.F.D. Herpetofauna da Reserva Ecológica de Guapiaçu (REGUA) e das áreas do entorno, no estado do Rio de Janeiro, Brasil. Biota Neotropica. 14(3): e20130078. http://dx.doi. org/10.1590/1676-0603007813

Resumo: Inventários de espécies constituem importantes subsídios para melhorar as estratégias de conservação, especialmente em biomas altamente ameaçados como a Mata Atlântica brasileira. Aqui, nós apresentamos uma lista de anfíbios e répteis para a Reserva Ecológica de Guapiaçu (REGUA), uma reserva florestal localizada na porção central do estado do Rio de Janeiro, Brasil. A lista é baseada em um esforço de amostragem extensivo de dez anos de duração. Um total de 73 espécies de anfíbios (das quais dez são endêmicas ao estado) e 37 espécies de répteis foi registrado na área. Cinco das espécies de anfíbios estão atualmente categorizadas pela IUCN como "deficiente em dados", duas como "quase ameaçadas" e uma como "em perigo", enquanto uma espécie de réptil está categorizada como "vulnerável". Nossos resultados mostram que a região da REGUA abriga cerca de um terço da herpetofauna atualmente conhecida para o estado do Rio de Janeiro, adicionando mais espécies em relação a listas de espécies anfíbios e répteis previamente publicadas para localidades na região da Serra dos Órgãos e enfatizando a importância desta área para a conservação dos anfíbios e répteis da Mata Atlântica.

Palavras-chave: anfíbios, Mata Atlântica, conservação, hotspot, répteis. 


\section{Introduction}

The Atlantic Forest is one of the world's most threatened biodiversity "hotspots" (Mittermeier et al. 2011) and despite being currently reduced to only about $12 \%$ of its original area, it still harbors great diversity and high rates of endemism for several animal groups (Ribeiro et al. 2009). More than 500 amphibian and about 200 reptile species occur in this biome (Ribeiro et al. 2009, Haddad et al. 2013). For the state of Rio de Janeiro there are nearly 200 amphibian and over 130 reptile species currently reported (Vrcibradic et al. 2011b), with both new geographic distribution records (e.g. Vrcibradic et al. 2006a, b, Goyannes-Araújo et al. 2009, Silveira et al. 2009, Caram et al. 2011) and descriptions/revalidations of taxa (particularly for amphibians; e.g. Canedo \& Pombal 2007, Pombal et al. 2008, Pombal 2010, Weber et al. 2011, Dias et al. 2013, Caramaschi \& Cruz 2013, Mângia et al. 2014) having recently added more species to the amphibian and reptile lists previously compiled by Rocha et al. (2004).

Collections of field data and species inventories are urgent to guide species conservation in Brazil (Verdade et al. 2012). Despite the increasing number of amphibian and/or reptile species lists for various localities in the state of Rio de Janeiro in the last ten years (e.g. Rocha \& Van Sluys 2006, AlmeidaGomes et al. 2008, 2010, Carvalho-e-Silva et al. 2008, Salles et al. 2009, 2010, Salles \& Silva-Soares 2010, Siqueira et al. 2011a, b, Vrcibradic et al. 2011b, Telles et al. 2012, Bittencourt-Silva \& Silva 2013, Rocha et al. 2013), there are some areas that still need more studies in order to provide a comprehensive characterization of their herpetofaunas.

The Reserva Ecológica de Guapiaçu (REGUA) is a private reserve, which has an area of nearly 7,600 ha. REGUA together with other conservation units such as Parque Estadual dos Três Picos ( $c a .46,000$ ha), Parque Nacional da Serra dos Órgãos ( $c a$. 11,800 ha), and Estação Ecológica Estadual do Paraíso (ca. $5,000 \mathrm{ha}$ ) protects a large continuous area of wet Atlantic Forest (mostly represented by montane and low montane rainforest) covering much of the region of Serra dos Órgãos, which comprises one of the areas of highest biodiversity in the state (Rocha et al. 2003).
Information on the herpetofauna of REGUA currently consists of a first approach on the local forest floor leaf-litter amphibian community, derived from data obtained in a shortterm inventory conducted in 2004 (Rocha et al. 2007), and a first approach on the local lizard fauna based on a study carried out between 2007 and 2010 (Almeida-Gomes \& Rocha in press). Besides, there are isolated occurrence records and ecological observations on some species of frogs (Weber et al. 2007, 2009, Silva-Soares et al. 2008, Klaion et al. 2011, MaiaCarneiro et al. 2012a, b, 2013, Salles et al. 2012, Siqueira et al. 2013), lizards (Goyannes-Araújo et al. 2009, Maia et al. 2011, Almeida-Gomes et al. 2012), and snakes (Alves et al. 2005, Silveira et al. 2010, Vrcibradic et al. 2011a). Here, we present the list of amphibian and reptile species based on records obtained during nearly ten years of surveys at REGUA and its surroundings.

\section{Material and Methods}

\section{Study area}

The Reserva Ecológica de Guapiaçu (REGUA) (22²4'S, $42^{\circ} 44^{\prime} \mathrm{W}$ ) is located at the slopes of the Serra dos Órgãos mountain range, in the municipality of Cachoeiras de Macacu, state of Rio de Janeiro, Brazil (Figure 1). In the continuous forest of REGUA, habitats range from secondary forests in early stages of ecological succession to areas of relatively little disturbed forest, in the higher and more inaccessible portions of the reserve (Rocha et al. 2007). In the surroundings of REGUA there are forest fragments of different sizes and degrees of regeneration and isolation, which are immersed in different types of matrix (mainly pastures) (Almeida-Gomes \& Rocha 2014). The region has a mean annual precipitation of $2600 \mathrm{~mm}$, with daily temperatures ranging from 14 to $37{ }^{\circ} \mathrm{C}$ (Bernardo et al. 2011).

\section{Data collection}

The amphibians and reptiles were sampled mainly within the continuous forest of REGUA, but also in 21 forest fragments (totaling nearly 1,300 ha of forested area), and in
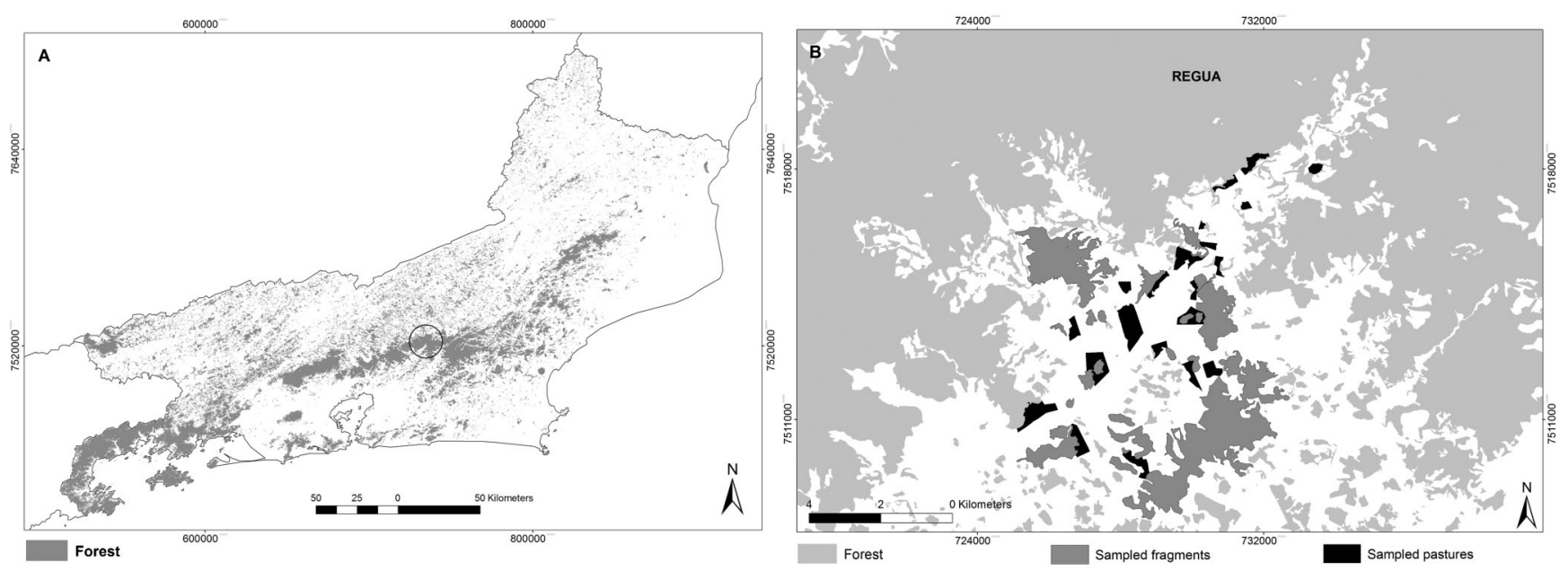

Figure 1. (A) Location of Reserva Ecológica de Guapiaçu (REGUA) in the state of Rio de Janeiro, Brazil (open circle) and (B) detail of the study area showing the continuous forest of REGUA, the sampled forest fragments and the sampled pasture areas (matrix). 
the surrounding pasture matrix (besides some anthropogenic habitats such as roads). Samplings were done during September 2004 and from July 2007 to February 2014 at altitudes ranging from ca. $30 \mathrm{~m}$ to $700 \mathrm{~m}$. We used three different methods for herpetofaunal sampling: pitfall traps with drift fences (Corn 1994), time-constrained visual encounter surveys (VES; Crump $\&$ Scott 1994) and quadrats $\left(16 \mathrm{~m}^{2}\right.$ and $25 \mathrm{~m}^{2}$ plots; Jaeger \& Inger 1994). The total sampling effort for each method was 6600 bucket-days (for pitfalls), 2631 hours (for VES) and $4750 \mathrm{~m}^{2}$ of forest floor surveyed (for quadrat method). Except for pasture areas (sampled only by VES), we used the three sampling methods in the continuous forest of REGUA and in forest fragments. Besides, we also recorded all specimens of amphibians and reptiles found during casual encounters (i.e. not using the above methodologies). Voucher specimens of all sampled species of the local herpetofauna were deposited at the Museu Nacional do Rio de Janeiro - MNRJ (Appendix 1), except for a few species of reptiles (the lizards Ameiva ameiva and Salvator merianae, the snakes Boa constrictor, Chironius laevicollis, Pseustes sulphureus and Spilotes pullatus, and the crocodylian Caiman latirostris); in all those cases the specimens found were too large for preservation and storage (considering the material we had available) or could not be collected (in the case of Ameiva ameiva). Also, one amphibian species
(Vitreorana sp.) was recorded based on an observation of an individual that evaded capture. Identification of all specimens of amphibians and reptiles collected were confirmed by taxonomists from the Museu Nacional, Rio de Janeiro; the specimens that were not collected were identified in the field by the authors. For amphibian nomenclature used throughout the text we follow Frost (2013), and regarding reptile nomenclature we follow Carrasco et al. (2012) for viperid snakes, Harvey et al. (2012) for teiid lizards, and Pyron et al. (2013) for the remaining groups.

\section{Results and Discussion}

We recorded 73 species of amphibians (71 anurans and two caecilians) (Table 1; Figures 2-5) and 37 species of reptiles (10 lizards, 24 snakes, one amphisbaenian, one chelonian and one crocodylian) (Table 2; Figures 6-8). The species richness we recorded in the area corresponds to $c a$. $40 \%$ and $c a$. $30 \%$ of the total species richness of, respectively, amphibians and reptiles known to occur in the state of Rio de Janeiro (see Vrcibradic et al. 2011b). Regarding the anurofauna in particular, the species richness reported here for REGUA is the highest yet reported for Atlantic Forest areas in which anuran surveys have been conducted, with only the Estação

Table 1. Amphibian species of the Reserva Ecológica de Guapiaçu (REGUA) and its surroundings, municipality of Cachoeiras de Macacu, state of Rio de Janeiro, Brazil. The habitats where they have been recorded are represented by: CF - continuous forest of REGUA; FF - forest fragments; and M - matrix habitats (composed of pastures, wetlands and anthropogenic areas). * Species endemic to state of Rio de Janeiro.

\begin{tabular}{|c|c|}
\hline TAXA & HABITAT \\
\hline \multicolumn{2}{|l|}{ ANURA } \\
\hline \multicolumn{2}{|l|}{ Brachycephalidae } \\
\hline Brachycephalus didactylus (Izecksohn, 1971) & $\mathrm{CF}, \mathrm{FF}$ \\
\hline Brachycephalus ephippium (Spix, 1824) & $\mathrm{CF}$ \\
\hline Ischnocnema guentheri (Steindachner, 1864) & $\mathrm{CF}, \mathrm{FF}$ \\
\hline Ischnocnema octavioi (Bokermann, 1965) & $\mathrm{CF}, \mathrm{FF}$ \\
\hline Ischnocnema parva (Girard, 1853) & $\mathrm{CF}$ \\
\hline Ischnocnema cf. venancioi (Lutz, 1958) & $\mathrm{CF}$ \\
\hline \multicolumn{2}{|l|}{ Bufonidae } \\
\hline Dendrophryniscus brevipollicatus Jiménez de la Espada, 1870 & $\mathrm{CF}$ \\
\hline Rhinella hoogmoedi Caramaschi and Pombal, 2006 & $\mathrm{CF}$ \\
\hline Rhinella icterica (Spix, 1824) & $\mathrm{CF}, \mathrm{FF}, \mathrm{M}$ \\
\hline Rhinella ornata (Spix, 1824) & $\mathrm{CF}, \mathrm{FF}, \mathrm{M}$ \\
\hline \multicolumn{2}{|l|}{ Centrolenidae } \\
\hline Vitreorana sp. & $\mathrm{CF}$ \\
\hline \multicolumn{2}{|l|}{ Craugastoridae } \\
\hline Euparkerella brasiliensis (Parker, 1926) * & $\mathrm{CF}, \mathrm{FF}$ \\
\hline Haddadus binotatus (Spix, 1824) & $\mathrm{CF}, \mathrm{FF}$ \\
\hline \multicolumn{2}{|l|}{ Cycloramphidae } \\
\hline Cycloramphus brasiliensis (Steindachner, 1864) * & $\mathrm{CF}$ \\
\hline Thoropa miliaris (Spix, 1824) & $\mathrm{CF}, \mathrm{FF}$ \\
\hline Zachaenus parvulus (Girard, 1853) & $\mathrm{CF}$ \\
\hline \multicolumn{2}{|l|}{ Hemiphractidae } \\
\hline Fritziana goeldii (Boulenger, 1895) & $\mathrm{CF}$ \\
\hline Gastrotheca albolineata (Lutz and Lutz, 1939) & $\mathrm{CF}$ \\
\hline \multicolumn{2}{|l|}{ Hylidae } \\
\hline Aplastodiscus eugenioi (Carvalho-e-Silva and Carvalho-e-Silva, 2005) & $\mathrm{CF}, \mathrm{FF}$ \\
\hline Bokermannohyla circumdata (Cope, 1871) & $\mathrm{CF}$ \\
\hline Dendropsophus anceps (Lutz, 1929) & $\mathrm{FF}, \mathrm{M}$ \\
\hline Dendropsophus berthalutzae (Bokermann, 1962) & $\mathrm{CF}, \mathrm{FF}, \mathrm{M}$ \\
\hline
\end{tabular}


Table 1. Continued.

\begin{tabular}{|c|c|}
\hline TAXA & HABITAT \\
\hline Dendropsophus bipunctatus (Spix, 1824) & $\mathrm{FF}, \mathrm{M}$ \\
\hline Dendropsophus decipiens (Lutz, 1925) & $\mathrm{FF}, \mathrm{M}$ \\
\hline Dendropsophus elegans (Wied-Neuwied, 1824) & $\mathrm{CF}, \mathrm{FF}, \mathrm{M}$ \\
\hline Dendropsophus giesleri (Mertens, 1950) & $\mathrm{FF}$ \\
\hline Dendropsophus meridianus (Lutz, 1954) & $\mathrm{FF}, \mathrm{M}$ \\
\hline Dendropsophus microps (Peters, 1872) & M \\
\hline Dendropsophus minutus (Peters, 1872) & FF, M \\
\hline Dendropsophus pseudomeridianus (Cruz, Caramaschi and Dias, 2000) & $\mathrm{FF}, \mathrm{M}$ \\
\hline Dendropsophus seniculus (Cope, 1868) & $\mathrm{CF}, \mathrm{FF}, \mathrm{M}$ \\
\hline Hypsiboas albomarginatus (Spix, 1824) & $\mathrm{CF}, \mathrm{FF}, \mathrm{M}$ \\
\hline Hypsiboas albopunctatus (Spix, 1824) & M \\
\hline Hypsiboas faber (Wied-Neuwied, 1821) & $\mathrm{CF}, \mathrm{FF}, \mathrm{M}$ \\
\hline Hypsiboas pardalis (Spix, 1824) & $\mathrm{CF}, \mathrm{M}$ \\
\hline Hypsiboas secedens (Lutz, 1963)* & $\mathrm{CF}, \mathrm{FF}$ \\
\hline Hypsiboas semilineatus (Spix, 1824) & $\mathrm{CF}, \mathrm{FF}, \mathrm{M}$ \\
\hline Itapotihyla langsdorffii (Duméril and Bibron, 1841) & $\mathrm{FF}$ \\
\hline Phyllomedusa burmeisteri (Boulenger, 1882) & $\mathrm{CF}, \mathrm{FF}, \mathrm{M}$ \\
\hline Phyllomedusa rohdei Mertens, 1926 & $\mathrm{CF}, \mathrm{FF}, \mathrm{M}$ \\
\hline Scinax albicans (Bokermann, 1967) * & $\mathrm{CF}$ \\
\hline Scinax alter (Lutz, 1973) & M \\
\hline Scinax argyreornatus (Miranda-Ribeiro, 1926) & $\mathrm{CF}, \mathrm{FF}, \mathrm{M}$ \\
\hline Scinax cuspidatus (Lutz, 1925) & $\mathrm{FF}, \mathrm{M}$ \\
\hline Scinax flavoguttatus (Lutz and Lutz, 1939) & $\mathrm{CF}$ \\
\hline Scinax hayii (Barbour, 1909) & $\mathrm{CF}$ \\
\hline Scinax humilis (Lutz and Lutz, 1954) * & $\mathrm{CF}, \mathrm{FF}, \mathrm{M}$ \\
\hline Scinax v-signatus (Lutz, 1968)* & $\mathrm{CF}$ \\
\hline Scinax aff. $x$-signatus & $\mathrm{CF}, \mathrm{FF}, \mathrm{M}$ \\
\hline Sphaenorhynchus planicola (Lutz and Lutz, 1938) & $\mathrm{M}$ \\
\hline Trachycephalus mesophaeus (Hensel, 1867) & $\mathrm{CF}, \mathrm{FF}, \mathrm{M}$ \\
\hline Trachycephalus nigromaculatus Tschudi, 1838 & $\mathrm{FF}$ \\
\hline \multicolumn{2}{|l|}{ Hylodidae } \\
\hline Crossodactylus aeneus Müller, 1924 & $\mathrm{CF}$ \\
\hline Hylodes asper (Müller, 1924) & $\mathrm{CF}$ \\
\hline Hylodes charadranaetes Heyer and Cocroft, 1986 * & $\mathrm{CF}$ \\
\hline Hylodes lateristrigatus (Baumann, 1912) & $\mathrm{CF}$ \\
\hline Hylodes pipilans Canedo and Pombal $2007 *$ & $\mathrm{CF}$ \\
\hline Megaelosia goeldii (Baumann, 1912) & $\mathrm{CF}$ \\
\hline \multicolumn{2}{|l|}{ Leptodactylidae } \\
\hline Adenomera cf. bokermanni (Heyer 1973) & M \\
\hline Adenomera marmorata Steindachner, 1867 & $\mathrm{CF}, \mathrm{FF}, \mathrm{M}$ \\
\hline Leptodactylus fuscus (Schneider, 1799) & M \\
\hline Leptodactylus latrans (Steffen, 1815) & $\mathrm{CF}, \mathrm{FF}, \mathrm{M}$ \\
\hline Leptodactylus mystacinus (Burmeister, 1861) & $\mathrm{FF}$ \\
\hline Leptodactylus spixi Heyer, 1983 & FF \\
\hline Physalaemus signifer (Girard, 1853) & $\mathrm{CF}, \mathrm{FF}, \mathrm{M}$ \\
\hline \multicolumn{2}{|l|}{ Microhylidae } \\
\hline Chiasmocleis carvalhoi Cruz, Caramaschi and Izecksohn, 1997 & $\mathrm{CF}, \mathrm{FF}$ \\
\hline Myersiella microps (Duméril and Bibron, 1841) & FF \\
\hline Stereocyclops parkeri (Wettstein, 1934) & FF \\
\hline \multicolumn{2}{|l|}{ Odontophrynidae } \\
\hline Proceratophrys appendiculata (Günther, 1873) * & $\mathrm{CF}$ \\
\hline Proceratophrys boiei (Wied-Neuwied, 1824) & $\mathrm{CF}$ \\
\hline \multicolumn{2}{|l|}{ Ranidae } \\
\hline Lithobates catesbeianus (Shaw, 1802) & M \\
\hline \multicolumn{2}{|l|}{ GYMNOPHIONA } \\
\hline \multicolumn{2}{|l|}{ Siphonopidae } \\
\hline Siphonops hardyi Boulenger, 1888 & $\mathrm{CF}$ \\
\hline \multicolumn{2}{|l|}{ Typhlonectidae } \\
\hline Chthonerpeton braestrupi Taylor, 1968 & FF \\
\hline
\end{tabular}



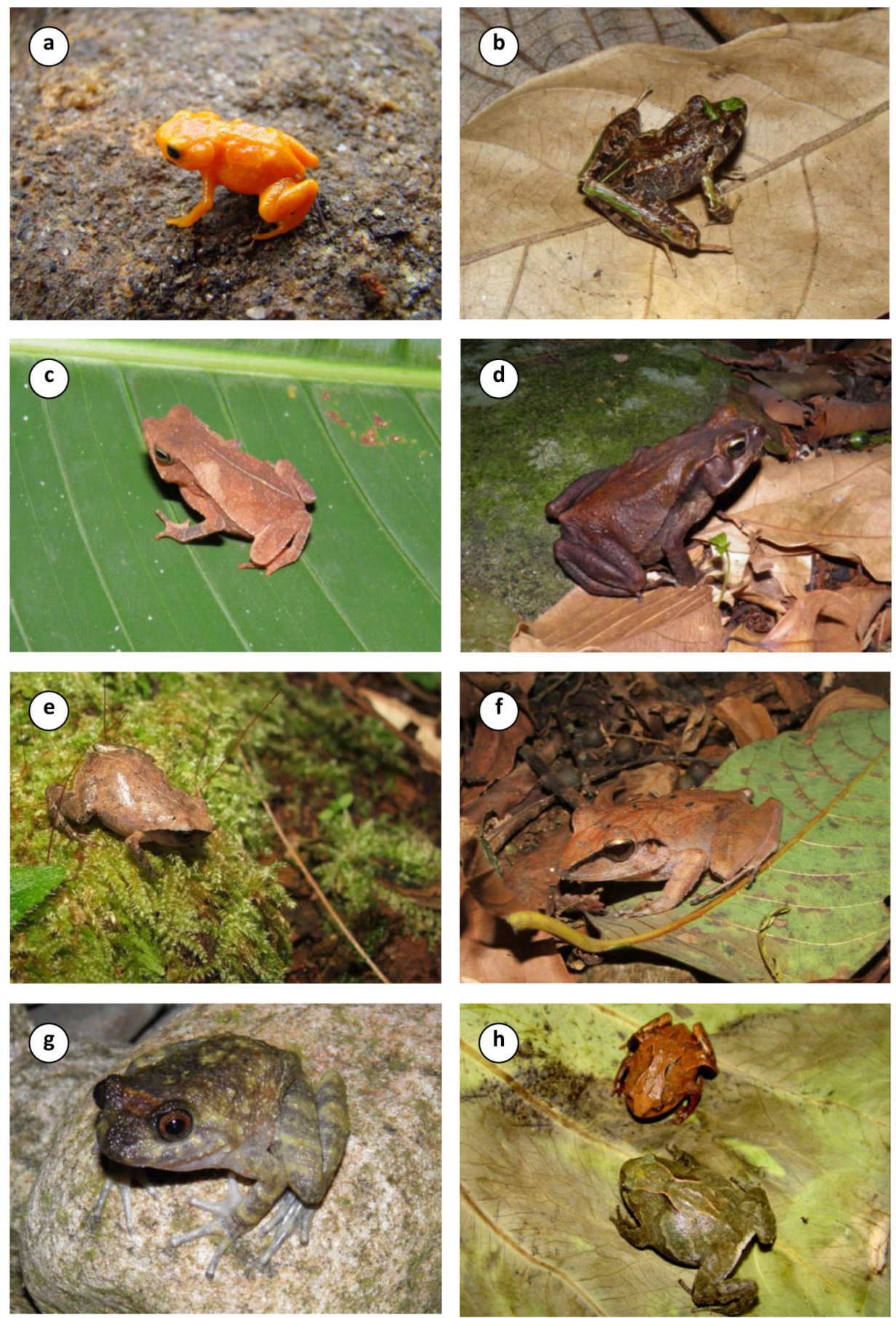

Figure 2. Some anurans recorded in the Reserva Ecológica de Guapiaçu, southeastern Brazil: a) Brachycephalus ephippium; b) Ischnocnema guentheri; c) Rhinella hoogmoedi; d) Rhinella ornata; e) Euparkerella brasiliensis; f) Haddadus binotatus; g) Cycloramphus brasiliensis; h) Zachaenus parvulus. Photos by M. Almeida-Gomes (a, b, c, h) and D. Vrcibradic (d, e, f, g).

Biológica de Boracéia (in São Paulo state) presenting a comparable richness (see review in Salles et al. 2009). This reflects the intensive and extensive sampling effort employed in our study and the diversity of habitats (including both forested and open areas) and altitudinal gradient $(30-700 \mathrm{~m})$ surveyed, all of which likely maximized our potential to sample a representative portion of the region's anuran diversity. The reptile richness reported here for REGUA is likely underestimated, but is still among the highest recorded for inventoried areas of Atlantic Forest (see review in Salles et al. 2010). Our study represents a further contribution to the knowledge of the herpetofauna of the Serra dos Órgãos region, adding more information to previously published lists of amphibians and reptiles from other localities within that region (Siqueira et al. 2009, 2011b, Silva-Soares et al. 2010, Vrcibradic et al. 2011b). 

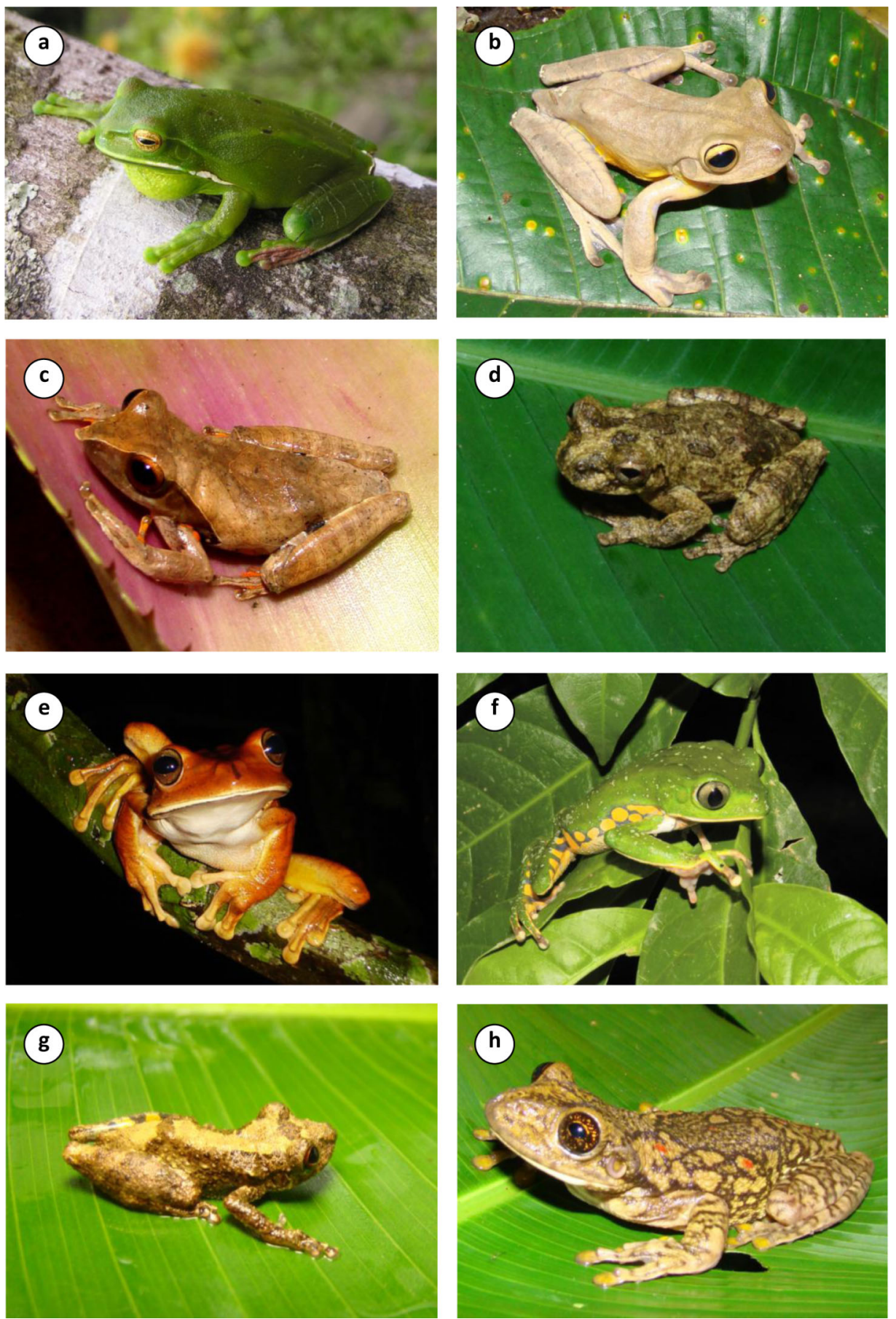

Figure 3. Some anurans recorded in the Reserva Ecológica de Guapiaçu, southeastern Brazil: a) Gastrotheca albolineata; b) Bokermannohyla circumdata; c) Dendropsophus anceps; d) Dendropsophus seniculus; e) Hypsiboas faber; f) Phyllomedusa burmeisteri; g) Scinax v-signatus; h) Trachycephalus nigromaculatus. Photos by L. Fusinatto (a, f), M. Almeida-Gomes (b, c, d, g, h) and V. Borges-Júnior (e).

Of the 73 amphibian species recorded, $25(34 \%)$ were found only in continuous forest, whereas $17(23 \%)$ were found in all three types of habitats (continuous forest, forest fragments and matrix) (Table 1). Of the 37 reptile species recorded, $13(35 \%)$ were found only in continuous forest, whereas four (11\%) were found only in matrix habitat (Table 2). Landscape heterogeneity (continuous forest, forest fragments and matrix habitats) allows for different forms of occupation by species of the herpetofauna (Almeida-Gomes et al. 2010, Dixo \& Metzger 2010; Almeida-Gomes \& Rocha 2014, Almeida-Gomes \& Rocha in press), as observed in the present study at REGUA. The amphibian community was dominated by species of the family Hylidae ( $33 \mathrm{spp}$.), many of them found in disturbed landscapes, where they commonly use permanent or temporary ponds for reproduction (e.g. Almeida-Gomes et al. 2008, 2010). Among reptiles, some species such as the crocodylian Caiman 

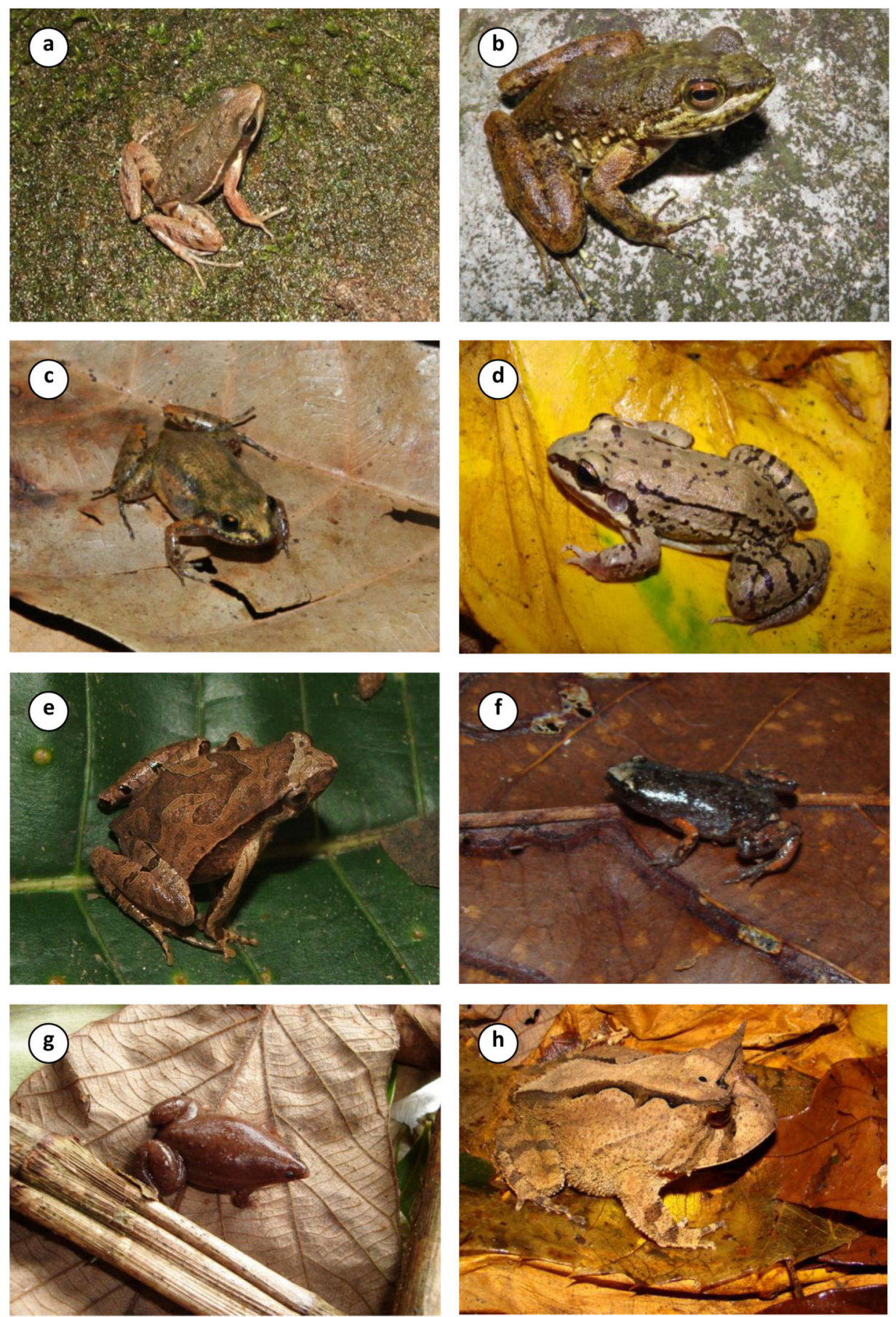

Figure 4. Some anurans recorded in the Reserva Ecológica de Guapiaçu, southeastern Brazil: a) Hylodes charadranaetes; b) Megaelosia goeldii; c) Adenomera marmorata; d) Leptodactylus mystacinus; e) Physalaemus signifer; f) Chiasmocleis carvalhoi; g) Myersiella microps; h) Proceratophrys boiei. Photos by D. Vrcibradic (a, b, e), L. Fusinatto (c), M. Almeida-Gomes (d, f, h) and V. Borges-Júnior (g).

latirostris (broad-snouted caiman) were found only in the matrix habitat (specifically in wetlands and ponds). Thus, not only the forested habitats but also the matrix habitats are responsible for maintaining the great local diversity of amphibians and reptiles observed at REGUA.

We recorded two exotic species among the herpetofauna of REGUA: the African gekkonid lizard Hemidactylus mabouia (tropical house gecko) and the North American ranid frog Lithobates catesbeianus (American bullfrog). It is noteworthy that we recorded the presence of $H$. mabouia in natural areas inside some forest fragments sharing the habitat with native lizards. This indicates that $H$. mabouia has become an invasive species in remnants of Atlantic Forest in the area, as reported for other localities in Brazil (Anjos \& Rocha 2008, Rocha et al. 2011). However, this species has not been recorded so far within the continuous forest of REGUA, only in fragments and in the matrix habitat. This suggests that $H$. mabouia may have a limited ability to colonize the more preserved forest habitats in 

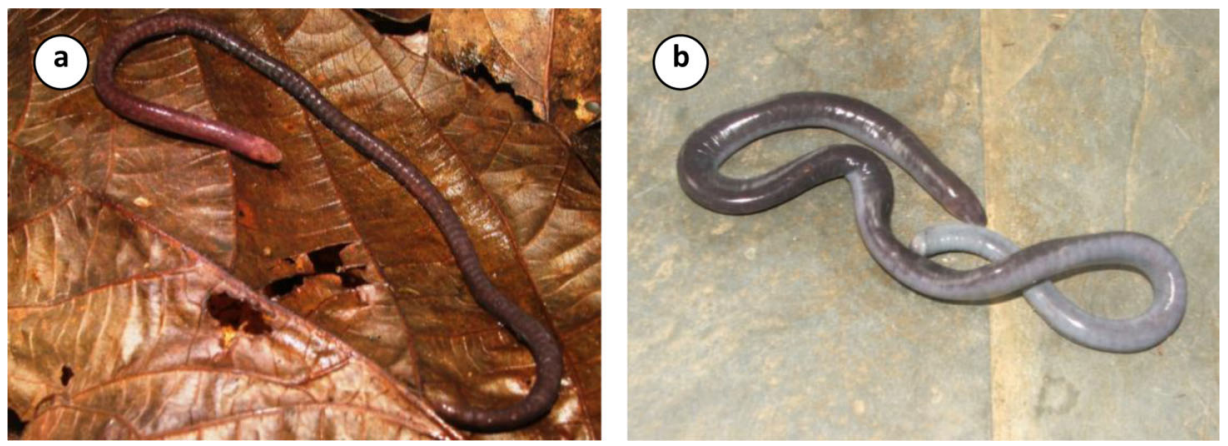

Figure 5. Gymnophiona recorded in the Reserva Ecológica de Guapiaçu, southeastern Brazil: a) Siphonops hardyi; b) Chthonerpeton braestrupi. Photos by D. Vrcibradic.

the area, especially far from forest edges. On the other hand, we found the bullfrog L. catesbeianus only in matrix habitats, with no records of the species occurring in natural habitats within the reserve. This suggests that $L$. catesbeianus may not have become an invasive species in the area and is possibly confined to perianthropic environments. The status of introduced American bullfrog populations in Brazil and their actual impact on natural ecosystems are currently not well known, despite this species having been reported in the wild from numerous localities in Brazil (Giovanelli et al. 2008, Both et al. 2011).

Regarding amphibians, nine species (Euparkerella brasiliensis, Cycloramphus brasiliensis, Proceratophrys appendiculata, Hypsiboas secedens, Scinax albicans, Scinax humilis, Scinax v-signatus, Hylodes charadranaetes, and Hylodes pipilans) are currently considered as endemic to state of Rio de Janeiro (Weber et al. 2009, Dias et al. 2013, Haddad et al. 2013, Silva \& Alves-Silva 2013), representing $12 \%$ of the species herein recorded. Five amphibian species (H. secedens, Crossodactylus aeneus, $H$. charadranaetes, $H$. pipilans and Chthonerpeton braestrupi) are presently categorized by the IUCN (2013) as "data-deficient", two (C. brasiliensis and Aplastodiscus eugenioi) as "near threatened", and one (Chiasmocleis carvalhoi) as "endangered". Among the reptile species recorded, one (the turtle Hydromedusa maximiliani) is presently categorized by the IUCN (2013) as "vulnerable". The presence of endemic species and species listed in threatened categories points to the potential of REGUA for species conservation. Moreover, three of the "data-deficient" species (Crossodactylus aeneus, $H$. charadranaetes, and $H$. pipilans) and the two near-threatened ones ( $C$. brasiliensis and $A$. eugenioi) have their life cycle restricted to streams inside forests, a life history characteristic that has been linked to amphibian declines in pristine areas (Stuart et al. 2004, Whiles et al. 2006), which points to the urgency of monitoring studies of these populations. A further interesting fact is that sites with "data-deficient" species may indicate high potential for discovery of new species (TrindadeFilho et al. 2012) suggesting that, besides the species recently described from the general area (e.g. Hylodes pipilans; Canedo \& Pombal 2007), there may be more unknown species to be found or described at REGUA and its surroundings (e.g. Gehara et al. 2013). Furthermore, some species currently recognized as data deficient might have their extinction threat underestimated (Almeida-Gomes et al. 2014), which makes it urgent to conduct further studies to assess their real population status.
Some of the amphibians recorded at REGUA present taxonomic problems. One caecilian collected in a large forest fragment while moving on the ground during a rainy night was identified as Chthonerpeton braestrupi by Dr Mark Wilkinson (Natural History Museum, London, UK). This species is currently known only from the original description by Taylor (1968), who gives an imprecise type locality ("Brazil"). Also, the sole type specimen is apparently lost (see Frost 2013). More sampling effort and study of Chthonerpeton specimens in zoological collections are needed to determine to which population(s) the name Chthonerpeton braestrupi can be applied. Among the frogs, Scinax aff. x-signatus apparently represents an undescribed species (M.C.S. Cardoso, pers. comm.). One glass frog (Vitreorana sp.) was seen on a bromeliad at night, but evaded capture and therefore could not be identified to species (no other glass frogs were seen during the study). The taxonomic status of populations currently attributed to Adenomera bokermanni is problematic, as the type series of that taxon is composed of more than one species (J.P. Pombal Jr, pers. comm.). Also, what we are treating here under the name Scinax v-signatus may represent more than one taxon. Finally, taxa such as Ischnocnema guentheri (Gehara et al. 2013), Euparkerella brasiliensis (Fusinatto et al. 2013), Adenomera marmorata (C.S. Cassini, pers. comm.), and Dendrophryniscus brevipollicatus (C.A.G. Cruz, pers. comm.) represent species complexes, and the taxonomic status and/or the number of taxa recognized under those names that occur at REGUA are not known at present.

Based on our extensive sampling effort, using different collecting methodologies during a long-term study, we believe that REGUA currently constitutes one of the most well studied areas in the state of Rio de Janeiro, regarding its herpetofauna. We believe that our species list is quite comprehensive (especially for amphibians) and represents a good approximation of the composition of the local herpetofauna, and that REGUA can be considered as a reservoir of a considerable portion of the state's amphibian and reptile biodiversity.

\section{Acknowledgments}

This study was supported by research grants from the Conselho Nacional de Desenvolvimento Científico e Tecnológico (CNPq) (processes 304791/2010-5 and 472287/ 2012-5) and from Fundação de Amparo à Pesquisa do Estado 
Table 2. Reptile species of the Reserva Ecológica de Guapiaçu (REGUA) and its surroundings, municipality of Cachoeiras de Macacu, state of Rio de Janeiro. The habitats where they have been recorded are represented by: CF - continuous forest of REGUA; FF - forest fragments; and M - matrix habitats (composed of pastures, wetlands and anthropogenic areas).

\begin{tabular}{|c|c|}
\hline TAXA & Habitat \\
\hline \multicolumn{2}{|l|}{ AMPHISBAENIA } \\
\hline \multicolumn{2}{|l|}{ Amphisbaenidae } \\
\hline Amphisbaena microcephala (Wagler, 1824) & $\mathrm{CF}$ \\
\hline \multicolumn{2}{|l|}{ LACERTILIA } \\
\hline \multicolumn{2}{|l|}{ Anguidae } \\
\hline Ophiodes striatus (Spix, 1824) & FF, M \\
\hline \multicolumn{2}{|l|}{ Dactyloidae } \\
\hline Anolis fuscoauratus D’Orbigny, 1837 & FF \\
\hline Anolis punctatus Daudin, 1802 & $\mathrm{CF}, \mathrm{FF}$ \\
\hline \multicolumn{2}{|l|}{ Gekkonidae } \\
\hline Hemidactylus mabouia (Moreau de Jonnès, 1818) & $\mathrm{FF}, \mathrm{M}$ \\
\hline \multicolumn{2}{|l|}{ Gymnophtalmidae } \\
\hline Ecpleopus gaudichaudii Duméril and Bibron, 1839 & $\mathrm{CF}, \mathrm{FF}$ \\
\hline \multicolumn{2}{|l|}{ Leiosauridae } \\
\hline Enyalius brasiliensis (Lesson, 1830) & $\mathrm{CF}, \mathrm{FF}$ \\
\hline \multicolumn{2}{|l|}{ Phyllodactylidae } \\
\hline Gymnodactylus darwinii (Gray, 1845) & FF \\
\hline \multicolumn{2}{|l|}{ Scincidae } \\
\hline Mabuya macrorhyncha Hoge, 1946 & $\mathrm{FF}, \mathrm{M}$ \\
\hline \multicolumn{2}{|l|}{ Teiidae } \\
\hline Ameiva ameiva (Linnaeus, 1758) & M \\
\hline Salvator merianae Duméril and Bibron, 1839 & $\mathrm{CF}, \mathrm{FF}$ \\
\hline \multicolumn{2}{|l|}{ SERPENTES } \\
\hline \multicolumn{2}{|l|}{ Boidae } \\
\hline Boa constrictor Linnaeus, 1758 & M \\
\hline Corallus hortulanus (Linnaeus, 1758) & $\mathrm{CF}, \mathrm{FF}$ \\
\hline \multicolumn{2}{|l|}{ Colubridae } \\
\hline Chironius bicarinatus (Wied, 1820) & $\mathrm{FF}$ \\
\hline Chironius foveatus Bailey, 1955 & $\mathrm{CF}$ \\
\hline Chironius fuscus (Linnaeus, 1758) & $\mathrm{CF}$ \\
\hline Chironius laevicollis (Wied, 1824) & M \\
\hline Echinanthera amoena (Jan, 1863) & $\mathrm{CF}$ \\
\hline Echinanthera cephalostriata Di Bernardo, 1996 & $\mathrm{CF}$ \\
\hline Helicops carinicaudus (Wied-Neuwied, 1825) & $\mathrm{CF}$ \\
\hline Imantodes cenchoa (Linnaeus, 1758) & $\mathrm{CF}$ \\
\hline Liophis miliaris (Linnaeus, 1758) & $\mathrm{FF}, \mathrm{M}$ \\
\hline Liophis reginae (Linnaeus, 1758) & $\mathrm{CF}, \mathrm{FF}$ \\
\hline Oxyrhopus clathratus Duméril, Bibron \& Duméril, 1854 & $\mathrm{CF}$ \\
\hline Oxyrhopus petolarius (Linnaeus, 1758) & $\mathrm{CF}, \mathrm{FF}$ \\
\hline Philodryas patagoniensis (Girard, 1858) & M \\
\hline Pseustes sulphureus (Wagler, 1824) & $\mathrm{CF}$ \\
\hline Sibynomorphus neuwiedi (Ihering, 1911) & $\mathrm{CF}, \mathrm{FF}$ \\
\hline Siphlophis compressus (Daudin, 1803) & $\mathrm{CF}$ \\
\hline Spilotes pullatus (Linnaeus, 1758) & $\mathrm{CF}, \mathrm{M}$ \\
\hline Taeniophallus affinis (Günther, 1858) & $\mathrm{CF}, \mathrm{FF}$ \\
\hline Xenodon neuwiedii Günther, 1863 & $\mathrm{CF}, \mathrm{FF}$ \\
\hline \multicolumn{2}{|l|}{ Elapidae } \\
\hline Micrurus corallinus (Merrem, 1820) & $\mathrm{CF}$ \\
\hline \multicolumn{2}{|l|}{ Viperidae } \\
\hline Bothrops jararaca (Wied, 1824) & $\mathrm{CF}, \mathrm{FF}$ \\
\hline Bothrops jararacussu Lacerda, 1884 & $\mathrm{CF}$ \\
\hline \multicolumn{2}{|l|}{ CROCODYLIA } \\
\hline \multicolumn{2}{|l|}{ Alligatoridae } \\
\hline Caiman latirostris (Daudin, 1802) & M \\
\hline \multicolumn{2}{|l|}{ TESTUDINES } \\
\hline Chelidae & \\
\hline Hydromedusa maximiliani (Mikan, 1820) & $\mathrm{CF}$ \\
\hline
\end{tabular}



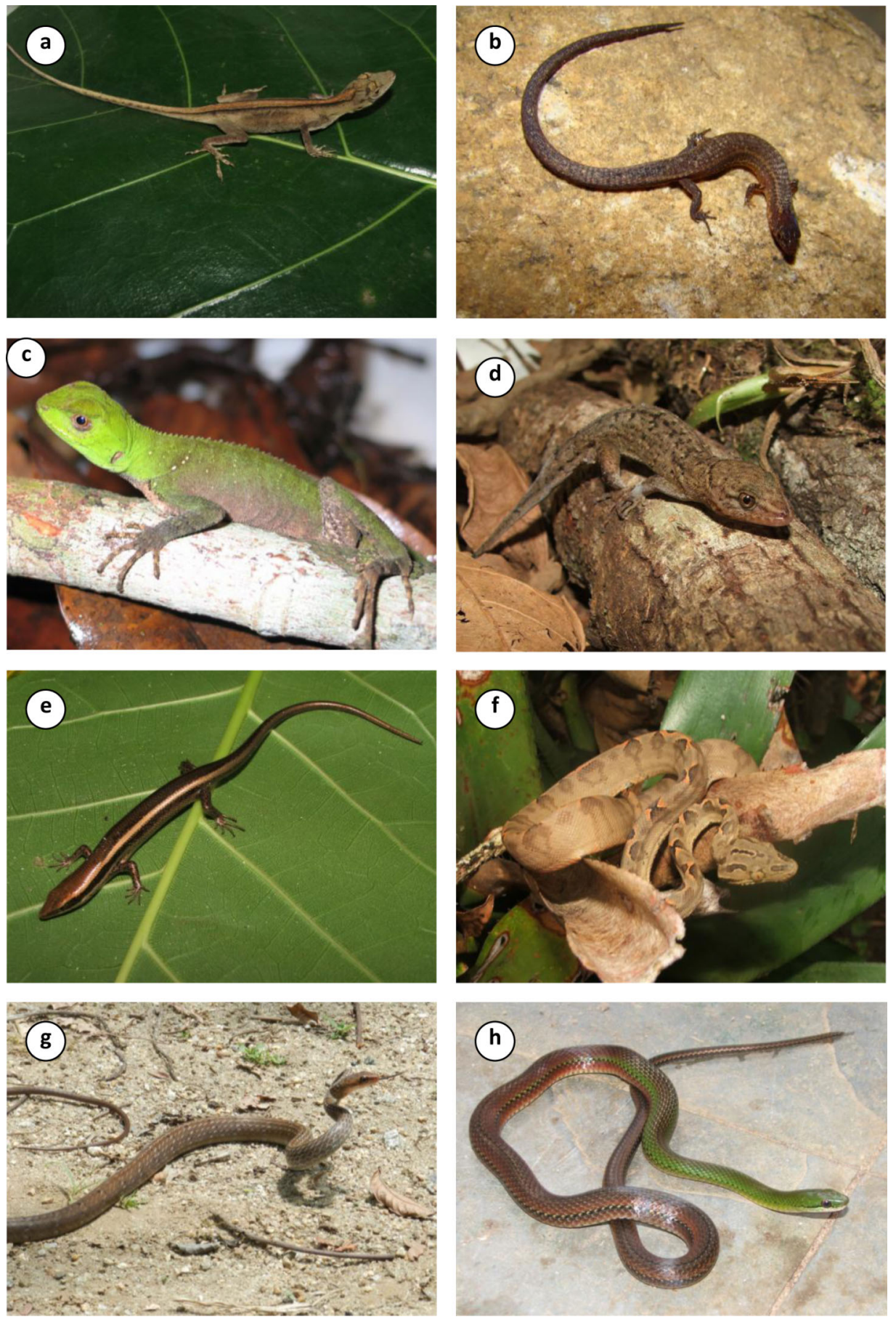

Figure 6. Some reptiles recorded in the Reserva Ecológica de Guapiaçu, southeastern Brazil: a) Anolis fuscoauratus; b) Ecpleopus gaudichaudii; c) Enyalius brasiliensis; d) Gymnodactylus darwinii; e) Mabuya macrorhyncha; f) Corallus hortulanus; g) Chironius fuscus; h) Echinanthera amoena. Photos by D. Vrcibradic (a, d, e, f, h), M. Almeida-Gomes (b), C.F. Rocha (c) and L. Fusinatto (g).

do Rio de Janeiro (FAPERJ) through "Cientistas do Nosso Estado" Program (process E-26/102.765/2012) to C. F. D. Rocha. This project also benefited from funding from the "Edital Espécies Ameaçadas" of Fundação Biodiversitas/ CEPAN and RAN/ICMBio (Project No. 0158A/012006). M. Almeida-Gomes received $\mathrm{PhD}$ scholarship from Conservation International - Brazil and FAPERJ, and currently receives a Post-Doctoral scholarship from Programa Nacional de Pós
Doutorado/Coordenação de Aperfeiçoamento de Pessoal de Nível Superior - PNPD/CAPES. C.C. Siqueira received a PhD scholarship from $\mathrm{CNPq}$, Post-Doctoral grants from $\mathrm{CNPq}$, and currently receives a Post-Doctoral fellowship from PNPDCAPES. V.N.T. Borges-Júnior received a PhD scholarship from CNPq, a "sandwich" $\mathrm{PhD}$ grant from Programa de Doutorado Sanduíche no Exterior - PDSE/CAPES, and currently receives a Post-Doctoral fellowship from Programa 

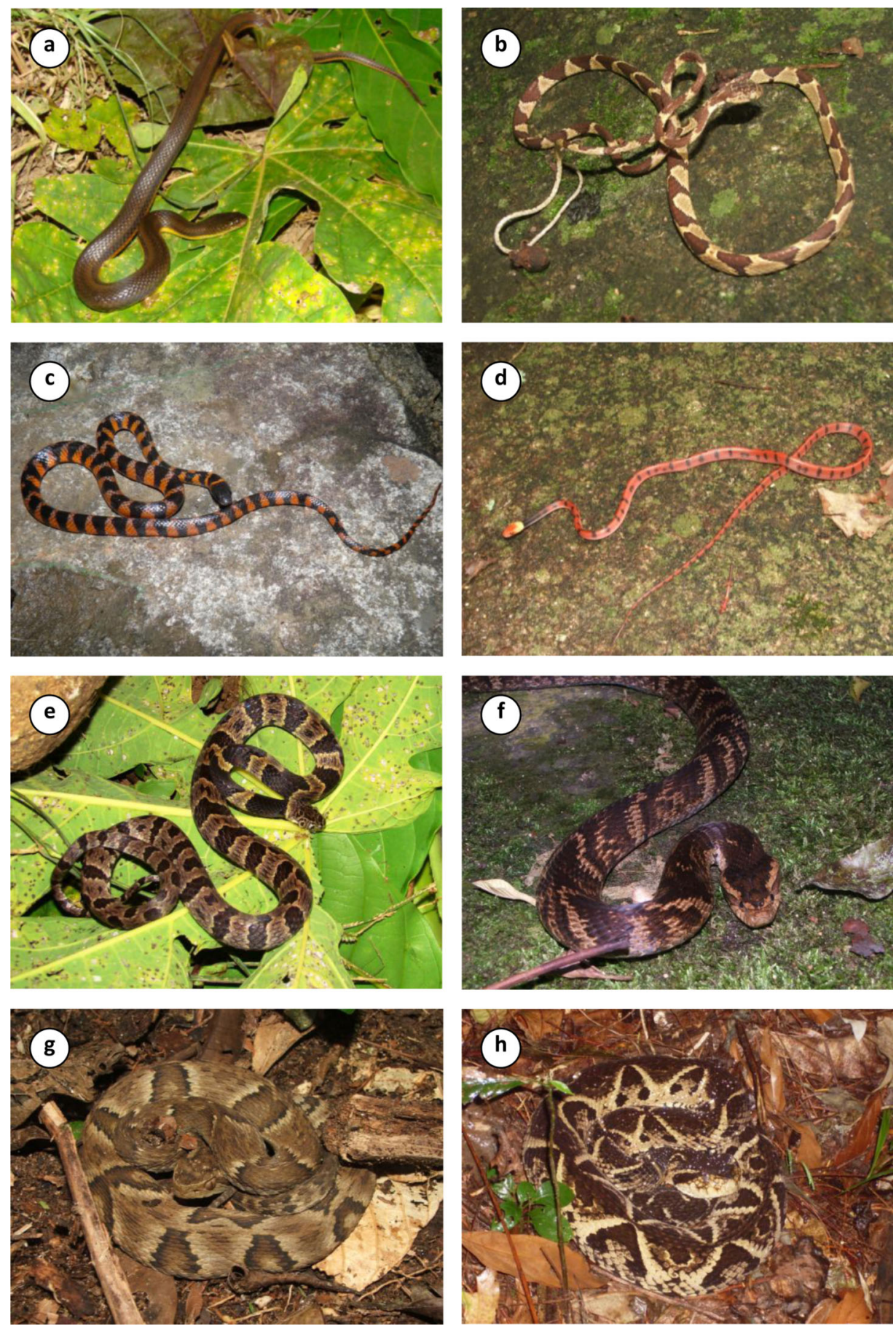

Figure 7. Some reptiles recorded in the Reserva Ecológica de Guapiaçu, southeastern Brazil: a) Helicops carinicaudus; b) Imantodes cenchoa; c) Oxyrhopus clathratus; d) Siphlophis compressus; e) Sibynomorphus neuwiedi; f) Xenodon neuwiedii; g) Bothrops jararaca; h) Bothrops jararacussu. Photos by M. Almeida-Gomes (a, e) and D. Vrcibradic (b, c, d, f, g, h).

de Apoio ao Pós-Doutorado - PAPD/FAPERJ. L. A. Fusinatto received a $\mathrm{PhD}$ scholarship from $\mathrm{CNPq}$ and a "sandwich" PhD grant from CAPES, and currently receives a Post-Doctoral fellowship from Fundação de Amparo à Pesquisa do Estado de São Paulo (FAPESP). We are grateful to Nicholas J. Locke of the Reserva Ecológica de Guapiaçu (REGUA) for making many facilities available during our fieldwork in that area, and to all the various colleagues who helped us with data collection. We thank the Instituto Estadual do Ambiente (INEA) for permission to work in the area (licenses \# 005/2008 and \# 010/2008) and the Instituto Chico Mendes de Conservação da Biodiversidade (ICMBio) for collection permits 11701-2, 13088-1, and 18684-2. We also thank the researchers of the Museu Nacional, Rio de Janeiro (MNRJ) for helping us with the identification of the amphibian and reptile species. 

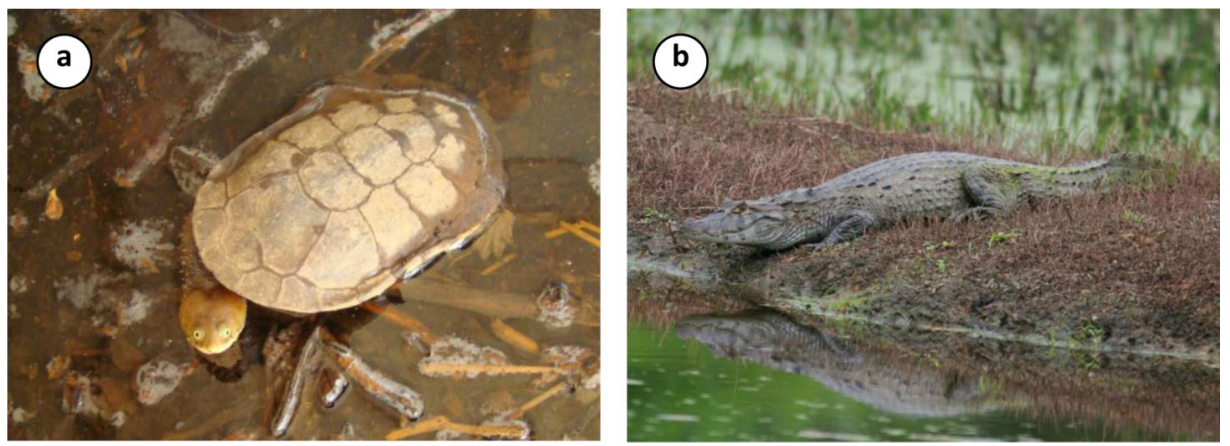

Figure 8. (a) The chelonian Hydromedusa maximiliani and (b) the crocodylian Caiman latirostris recorded in the Reserva Ecológica de Guapiaçu, southeastern Brazil. Photos by M. Almeida-Gomes (a) and Adilei da Cunha (b).

\section{References}

ALMEIDA-GOMES, M., ALMEIDA-SANTOS, M., GOYANNESARAÚJO, P., BORGES-JÚNIOR, V.N.T., VRCIBRADIC, D., SIQUEIRA, C.C., ARIANI, C.V., DIAS, A.S., SOUZA, V.V., PINTO, R.R., VANSLUYS, M \& ROCHA, C.F.D. 2010. Anurofauna of an Atlantic Rainforest fragment and its surroundings in northern Rio de Janeiro State, Brazil. Braz. J. Biol. 70(3):871-877. http://dx.doi.org/10.1590/S1519-69842010000400018

ALMEIDA-GOMES, M., LORINI, M.L., ROCHA C.F.D. \& VIEIRA, M.V. 2014. Underestimation of extinction threat to stream-dwelling amphibians due to lack of consideration of narrow area of occupancy. Conserv. Biol. 28(2):616-619. http://dx.doi.org/ 10.1111/cobi.12196

ALMEIDA-GOMES M. \& ROCHA, C.F.D. 2014. Landscape connectivity may explain anuran species distribution in an Atlantic forest fragmented area. Landscape Ecol. 29(1):29-40. http://dx.doi.org/10.1007/s10980-013-9898-5

ALMEIDA-GOMES, M. \& ROCHA, C.F.D. In press. Diversity and distribution of lizards in fragmented Atlantic Forest landscape in southeastern Brazil. J. Herpetol.

ALMEIDA-GOMES, M., VRCIBRADIC, D., MAIA-CARNEIRO, T. \& ROCHA, C.F.D. 2012. Diet and endoparasites of the lizard Gymnodactylus darwinii (Gekkota, Phyllodactylidae) from an Atlantic Rainforest area in southeastern Brazil. Biotemas 25(1):203-206. http:// dx.doi.org/10.5007/2175-7925.2012v25n1p203

ALMEIDA-GOMES, M., VRCIBRADIC, D., SIQUEIRA, C.C., KIEFER, M.C., KLAION, T., ALMEIDA-SANTOS, P., NASCIMENTO, D., ARIANI, C.V., BORGES-JÚNIOR, V.N.T., FREITAS-FILHO, R.F., VAN SLUYS, M \& ROCHA, C.F.D. 2008. Herpetofauna of an Atlantic Rainforest area (Morro São João) in Rio de Janeiro State, Brazil. An. Acad. Bras. Ciênc. 80(2):291-300. http://dx.doi.org/10.1590/S0001-37652008000200007

ALVES, M.A.S., ESBERARD, C.E.L., VECCHI, M.B., LAURINDO, T.F.S.\& TOMAZ, V.C. 2005. Pseutes sulphureus (South American Puffin Snake). Herpetol. Rev. 36(4):459.

ANJOS, L.A. \& ROCHA, C.F.D. 2008. The Hemidactylus mabouia Moreau de Jonnes, 1818 (Gekkonidae) lizard: an invasive alien species broadly distributed in Brazil. Nat. Conservação 6(1):196-207.

BERNARDO, C.S.S., LLOYD, H., BAYLY, N. \& GALETTI, M. 2011. Modelling post-release survival of reintroduced Red-billed Curassows Crax blumenbachii. Ibis 153(3):562-572. http:// dx.doi.org/10.1111/j.1474-919X.2011.01142.x

BITTENCOURT-SILVA, G.B. \& SILVA, H.R. 2013. Insular Anurans (Amphibia: Anura) of the coast of Rio de Janeiro, Southeast, Brazil. Check List 9(2):225-234.

BOTH, C., LINGNAU, R., SANTOS-JR, A.P., LIMA, L.P., MADALOZZO, B. \& GRANT, T. 2011. Widespread occurrence of the American bullfrog, Lithobates catesbeianus (Shaw, 1802) (Anura: Ranidae), in Brazil. S. Am. J. Herpetol. 6(2):127-134. http://dx.doi.org/10.2994/057.006.0203
CANEDO, C. \& POMBAL JR., J.P. 2007. Two new species of torrent frog of the genus Hylodes (Anura, Hylodidae) with nuptial thumb tubercles. Herpetologica 63(2):224-235. http://dx.doi.org/10.1655/ 0018-0831(2007)63[224:TNSOTF]2.0.CO;2

CARAM, J., LUNA-DIAS, C., GOMES, M.R. \& CARVALHO-ESILVA, S.P. 2011. Distribution extension of Scinax hiemalis (Haddad and Pombal, 1987) and new state record from Rio de Janeiro, southeastern Brazil (Amphibia: Anura: Hylidae). Herpetol. Notes 4:153-154.

CARAMASCHI, U. \& CRUZ, C.A.G. 2013. A new species of the Hypsiboas polytaenius clade from southeastern Brazil (Anura: Hylidae). S. Am. J. Herpetol. 8(2):121-126. http://dx.doi.org/ 10.2994/SAJH-D-13-00009.1

CARRASCO, P.A., MATTONI, C.I., LEYNAUD, G.C. \& SCROCCHI, G.J. 2012. Morphology, phylogeny and taxonomy of South American bothropoid pitvipers (Serpentes, Viperidae). Zool. Scr. 41(2):109-124. http://dx.doi.org/10.1111/j.14636409.2011.00511.x

CARVAlHO-E-SILVA, A.M.T., SILVA, G.R. \& CARVALHO-ESILVA, S.P. 2008. Anuros da Reserva Rio das Pedras, Mangaratiba, RJ, Brasil. Biota Neotrop. 8(1):199-209. http:// dx.doi.org/10.1590/S1676-06032008000100021

CORN, P.S. 1994. Straight-line drift fences and pitfall. In Measuring and monitoring biological diversity: standard methods for amphibians (R.W. Heyer, M.A. Donelly, R.A. McDiarmind, L.C. Heyek \& M.S. Foster, eds.). Smithsonian Institution Press, Washington DC, 109-117.

CRUMP, M.L. \& SCOTT, N.J. 1994. Visual encounter surveys. In Measuring and monitoring biological diversity: standard methods for amphibians (R.W. Heyer, M.A. Donelly, R.A. McDiarmind, L.C. Heyek \& M.S. Foster, eds.). Smithsonian Institution Press, Washington DC, 84-92.

DIAS, P.H.S., AMARO, R.C., CARVALHO-E-SILVA, A.M.P.T. \& RODRIGUES, M.T. 2013. Two new species of Proceratophrys Miranda-Ribeiro, 1920 (Anura; Odontophrynidae) from the Atlantic Forest, with taxonomic remarks on the genus. Zootaxa 3682(2):277-304. http://dx.doi.org/10.11646/zootaxa.3682.2.5

DIXO, M. \& METZGER, J.P. 2010. The matrix-tolerance hypothesis: an empirical test with frogs in the Atlantic Forest. Biodivers. Conserv. 19:3059-3071. http://dx.doi.org/10.1007/s10531-010-9878-x

FROST, D.R. 2013. Amphibian Species of the World: an Online Reference. Version 5.6 (9 January 2013). Electronic Database accessible at http://research.amnh.org/herpetology/amphibia/index. html. American Museum of Natural History, New York, USA. (last accessed on 20 August 2013)

FUSINATTO, L.A., ALEXANDRINO, J., HADDAD, C.F.B., BRUNES, T.O., ROCHA, C.F.D., SEQUEIRA, F. 2013. Cryptic genetic diversity is paramount in small-bodied amphibians of the genus Euparkerella (Anura: Craugastoridae) endemic to the Brazilian Atlantic Forest. PLoS One 8(11): e79504. http:// dx.doi.org/10.1371/journal.pone.0079504 
GEHARA, M., CANEDO, C., HADDAD, C.F.B. \& VENCES M. 2013. From widespread to microendemic: molecular and acoustic analyses show that Ischnocnema guentheri (Amphibia: Brachycephalidae) is endemic to Rio de Janeiro, Brazil. Conserv. Genet. 14. doi: 10.1007/s10592-013-0488-5, http://dx.doi.org/ 10.1007/s10592-013-0488-5

GIOVANELLI, J.G.R., HADDAD, C.F.B \& ALEXANDRINO, J. 2008. Predicting the potential distribution of the alien invasive American bullfrog (Lithobates catesbeianus) in Brazil. Biol. Invasions 10(5):585-590. http://dx.doi.org/10.1007/s10530-0079154-5

GOYANNES-ARAÚJO, P., ALMEIDA-GOMES, M., BORGESJÚNIOR, V.N.T., ALBUQUERQUE, H.G., VRCIBRADIC, D. \& ROCHA, C.F.D. 2009. Reptilia, Polychrotidae, Anolis fuscoauratus: Distribution extension. Check List 5(3):746-748.

HADDAD, C.F.B., TOLEDO, L.F., PRADO, C.P.A., LOEBMANN, D., GASPARINI, J.L. \& SAZIMA, I. 2013. Guia dos Anfíbios da Mata Atlântica: Diversidade e Biologia. Anolis Books, São Paulo, $543 \mathrm{p}$.

HARVEY, M.B., UGUETO, G.N. \& GUTBERLET, R.L. 2012. Review of teiid morphology with a revised taxonomy and phylogeny of the Teiidae (Lepidosauria: Squamata). Zootaxa, 3459:1-156.

IUCN, 2013.IUCN Red List of Threatened Species. Version 2013.1. $<$ www.iucnredlist.org > . (last accessed on 12 August 2013).

JAEGER, R. \& INGER, R.F. 1994. Standard techniques for inventory and monitoring: Quadrat Sampling. In Measuring and monitoring biological diversity: standard methods for amphibians (R.W. Heyer, M.A. Donelly, R.A. McDiarmind, L.C. Heyek \& M.S. Foster, eds.). Smithsonian Institution Press, Washington DC, 97-102.

KLAION, T., ALMEIDA-GOMES, M., TAVARES, L.E.R., ROCHA, C.F.D. \& VAN SLUYS, M. 2011. Diet and nematode infection in Proceratoprhys boiei (Anura: Cycloramphidae) from two Atlantic rainforest remnants in southeastern Brazil. An. Acad. Bras. Cienc. 83(4):1303-1312. http://dx.doi.org/10.1590/S000137652011000400017

MAIA, T., ALMEIDA-GOMES, M., SIQUEIRA, C.C., VRCIBRADIC, D., KIEFER, M.C. \& ROCHA, C.F.D. 2011. Diet of the leaf litter lizard Ecpleopus gaudichaudii (Gymnophtalmidae) in an Atlantic Rainforest area in Rio de Janeiro state, Brazil. Zoologia 28(5):587-592. http://dx.doi.org/ 10.1590/S1984-46702011000500006

MAIA-CARNEIRO, T., DORIGO, T.A., ALMEIDA-GOMES, M., VAN SLUYS, M \& ROCHA, C.F.D. 2012a. New altitudinal records of the endemic species Cycloramphus brasiliensis (Anura, Cycloramphidae) from the Atlantic Rainforest in the state of Rio de Janeiro, southeastern Brazil. Braz. J. Biol. 72(1):225-226. http:// dx.doi.org/10.1590/S1519-69842012000100029

MAIA-CARNEIRO, T., DORIGO, T.A., ALMEIDA-GOMES, M., VAN SLUYS, M \& ROCHA, C.F.D. 2012b. Feeding habits, microhabitat use, and daily activity of Cycloramphus brasiliensis (Anura: Cycloramphidae) from the Atlantic Rainforest, Brazil. Zoologia 29(3):277-279. http://dx.doi.org/10.1590/S198446702012000300007

MAIA-CARNEIRO, T., KIEFER, M.C., VAN SLUYS, M \& ROCHA, C.F.D. 2013. Feeding habits, microhabitat use, and daily activity period of Rhinella ornata (Anura, Bufonidae) from three Atlantic rainforest remnants in southeastern Brazil. NorthWest. J. Zool. 9(1):157-165.

MÂNGIA, S., SANTANA, D.J., CRUZ, C.A.G. \& FEIO, R.N. 2014. Taxonomic review of Proceratophrys melanopogon (MirandaRibeiro, 1926) with description of four new species (Amphibia, Anura, Odontophrynidae). Bol. Mus. Nac., N.S., Zool. 531:1-33.

MITTERMEIER, R.A., TURNER, W.R., LARSEN, F.W., BROOKS, T.M. \& GASCON, C. 2011. Global biodiversity conservation: the critical role of hotspots. In Biodiversity Hotspots (F.E. Zachos \& J.C. Habel, eds.). Springer-Verlag, Berlin, 3-22.
POMBAL JR., J.P. 2010. A posição taxonômica das "variedades" de Brachycephalus ephippium (Spix, 1824) descritas por MirandaRibeiro, 1920 (Amphibia: Anura: Brachycephalidae). Bol. Mus. Nac., N.S., Zool. 526:1-12.

POMBAL JR., J.P., SIQUEIRA, C.C., DORIGO, T.A., VRCIBRADIC, D., \& ROCHA, C.F.D. 2008. A third species of the rare frog genus Holoaden (Terrarana, Strabomantidae) from a montane rainforest area of southeastern Brazil. Zootaxa 1938:61-68.

PYRON, R.A., BURBRINK, F.T. \& J.J WIENS. 2013. A phylogeny and revised classification of Squamata, including 4161 species of lizards and snakes. BMC Evol. Biol. 13(93):1-53. http://dx.doi.org/ 10.1186/1471-2148-13-93

RIBEIRO, M.C., METZGER, J.P., MARTENSEN, A.C., PONZONI, F.J. \& HIROTA, M.M. 2009. The Brazilian Atlantic Forest: How much is left, and how is the remaining forest distributed? Implications for conservation. Biol. Conserv. 142(6):1141-1153. http://dx.doi.org/10.1016/j.biocon.2009.02.021

ROCHA, C.F.D. \& VAN SLUYS, M. 2006. New records of reptiles from Ilha Grande Island in Rio de Janeiro State, Brazil. Herpetol. Rev. 37(1):112-114.

ROCHA, C.F.D., BERGALlO, H.G., ALVES, M.A.S. \& VAN SLUYS S,. 2003. A Biodiversidade nos Grandes Remanescentes Florestais do Estado do Rio de Janeiro e nas Restingas da Mata Atlântica. RiMa, São Carlos, 160p.

ROCHA, C.F.D., BERGALLO, H.G., POMBAL JR., J.P., GEISE, L., VAN SLUYS, M., FERNANDES, R., \& CARAMASCHI, U. 2004. Fauna de anfíbios, répteis e mamíferos do Estado do Rio de Janeiro, sudeste do Brasil. Publ. Avul. Mus. Nac. 104:3-23.

ROCHA, C.F.D., ANJOS, L.A. \& BERGALlO, H.G. 2011. Conquering Brazil: the invasion by the exotic gekkonid lizard Hemidactylus mabouia (Squamata) in Brazilian natural environments. Zoologia 28(6):747-754. http://dx.doi.org/10.1590/S198446702011000600007

ROCHA, C.F.D., VRCIBRADIC, D., KIEFER, M.C., ALMEIDAGOMES, M., BORGES-JÚNIOR, V.N.T., CARNEIRO, P.C.F., MARRA, R.V., ALMEIDA-SANTOS, P., SIQUEIRA, C.C., GOYANNES-ARAÚJO, P., FERNANDES, C.G.A., RUBIÃO, E.C.N. \& VAN SLUYS, M. 2007. A survey of the leaf-litter frog assembly from an Atlantic forest area (Reserva Ecológica de Guapiaçu) in Rio de Janeiro State, Brazil, with an estimate of frog densities. Trop. Zool. 20(1):99-108.

ROCHA, C.F.D., VRCIBRADIC, D., KIEFER, M.C., ALMEIDAGOMES, M., BORGES-JÚNIOR, V.N.T., MENEZES, V.A., ARIANI, C.V., PONTES, J.A.L., GOYANNES-ARAÚJO, P., MARRA, R.V., GUEDES, D.M., SIQUEIRA, C.C. \& VAN SLUYS, M. 2013. The leaf-litter frog community from Reserva Rio das Pedras, Mangaratiba, Rio de Janeiro State, Southeastern Brazil: species richness, composition and densities. North-West. J. Zool. 9(1):151-156.

SALLES, R.O.L. \& SILVA-SOARES, T. 2010. Répteis do Município de Duque de Caxias, Baixada Fluminense, RJ, Brasil. Biotemas 23(2):135-144. http://dx.doi.org/10.5007/2175-7925.2010v23n2p135

SALLES, R.O.L., PONTES, R.C. \& SILVA-SOARES, T. 2012. New records and geographic distribution of Aplastodiscus eugenioi (Anura: Hylidae) in southeastern Brazil. Herpetol. Notes 5:431-433.

SALLES, R.O.L., WEBER, L.N. \& SILVA-SOARES, T. 2009. Amphibia, Anura, Parque Natural Municipal da Taquara, Municipality of Duque de Caxias, Rio de Janeiro State, Southeastern Brazil. Check List 5(4):840-854.

SALLES, R.O.L., WEBER, L.N. \& SILVA-SOARES, T. 2010. Reptiles, Squamata, Parque Natural Municipal da Taquara, Municipality of Duque de Caxias, State of Rio de Janeiro, Southeastern Brazil. Check List 6(2):280-286.

SILVA, H.R. \& ALVES-SILVA, R. 2013. Predictive-like distribution mapping using Google Earth: Reassessment of the distribution of the bromeligenous frog, Scinax v-signatus (Anura: Hylidae). Zootaxa 3609:213-222. http://dx.doi.org/10.11646/zootaxa.3609.2.7 
SILVA-SOARES, T., HEPP, F., COSTA, P.N., LUNA-DIAS, C., GOMES, M.R., CARVALHO-E-SILVA, A.M.P.T. \& CARVALHO-E-SILVA, S.P. 2010. Anfibios Anuros da RPPN Campo Escoteiro Geraldo Hugo Nunes, Município de Guapimirim, Rio de Janeiro, sudeste do Brasil. Biota Neotrop. 10(2):225-233. http://dx.doi.org/10.1590/S1676-06032010000200025

SILVA-SOARES, T., WEBER, L.N. \& SALLES, R.O.L. 2008. Amphibia, Anura, Hylidae, Hylodes pipilans: Distribution extension. Check List 4(3):295-296.

SILVEIRA, A.L., SALLES, R.O.L. \& PONTES, R.C. 2009. Primeiro registro de Rhinella pombali e novos registros de $R$. crucifer e $R$. ornata no Estado do Rio de Janeiro, Brasil (Amphibia, Anura, Bufonidae). Biotemas 22(4):231-235. http://dx.doi.org/10.5007/ 2175-7925.2009v22n4p231

SILVEIRA, A.L., VRCIBRADIC, D., ROCHA, C.F.D. \& SIQUEIRA, C.C. 2010. Geographic Distribution. Echinanthera amoena. Herpetol. Rev. 41(1):109.

SIQUEIRA, C.C., VRCIBRADIC, D., ALMEIDA-GOMES, M., BORGES-JÚNIOR, V.N.T., ALMEIDA-SANTOS, P., ALMEIDA-SANTOS, M., ARIANI, C.V., GUEDES, D.M., GOYANNES-ARAÚJO, P., DORIGO, T.A., VAN SLUYS, M \& ROCHA, C.F.D. 2009. Density and richness of leaf litter frogs (Amphibia: Anura) of an Atlantic Rainforest area in the Serra dos Órgãos, Rio de Janeiro State, Brazil. Zoologia 26(1):97-102. http:// dx.doi.org/10.1590/S1984-46702009000100015

SIQUEIRA, C.C., VRCIBRADIC, D., ALMEIDA-GOMES, M., MENEZES, V.A., BORGES-JÚNIOR, V.N.T., HATANO, F.H., PONTES, J.A.L., GOYANNES-ARAÚJO, P., GUEDES, D.M., VAN SLUYS M, \& ROCHA, C.F.D. 2011a. Species composition and density estimates of the anurofauna of a site within the northernmost large Atlantic Forest remnant (Parque Estadual do Desengano) in the state of Rio de Janeiro, Brazil. Biota Neotrop. 11(4):131-137. http://dx.doi.org/10.1590/S1676-06032011000400014

SIQUEIRA, C.C., VRCIBRADIC D., DORIGO, T.A. \& ROCHA, C.F.D. 2011b. Anurans from two high-elevation areas of Atlantic Forest in the state of Rio de Janeiro, Brazil. Zoologia 28(4):457464. http://dx.doi.org/10.1590/S1984-46702011000400007

SIQUEIRA, C.C., VRCIBRADIC D. \& ROCHA, C.F.D. 2013. Altitudinal records of data-deficient and threatened frog species from the Atlantic Rainforest of the Serra dos Órgãos mountains, in southeastern Brazil. Braz. J. Biol. 73(1):229-230. http://dx.doi.org/ 10.1590/S1519-69842013000100027

STUART, S.N., CHANSON, J.S., COX, N.A., YOUNG, B.E., RODRIGUES, A.S.L., FISCHMAN, D.L. \& WALLER, R.W. 2004. Status and trends of amphibian declines and extinctions worldwide. Science 306:1783-1785. http://dx.doi.org/10.1126/ science. 1103538

TAYLOR, E.H. 1968. The Caecilians of the World. A Taxonomic Review. University of Kansas Press, Lawrence. 848p.

TELLES, F.B.S., MENEZES, V.A., MAIA-CARNEIRO, T., DORIGO, T.A., WINCK, G.R. \& ROCHA, C.F.D. 2012.
Anurans from the 'Restinga' of Parque Natural Municipal de Grumari. Check List 8(6):1267-1273.

TRINDADE-FILHO, J., CARVALHO, R.A., BRITO, D. \& LOYOLA, R.D. 2012. How does the inclusion of Data Deficient species change conservation priorities for amphibians in the Atlantic Forest? Biodivers. Conserv. 21(10):2709-2718. http:// dx.doi.org/10.1007/s10531-012-0326-y

VERDADE, V.K., VALDUJO, P.H., CARNAVAL, A.C., SCHIESARI, L., TOLEDO, L.F., MOTT, T., ANDRADE, G.V., ETEROVICK, P.C., MENIN, M., PIMENTA, B.V.S., NOGUEIRA, C., LISBOA, C.S., DE PAULA C.D. \& SILVANO, D.L. 2012. A leap further: the Brazilian amphibian conservation action plan. Alytes 29(1-4):28-43.

VRCIBRADIC, D., ALMEIDA-GOMES, M., BORGES-JÚNIOR, V.N.T., KIEFER, M.C., VAN SLUYS, M \& ROCHA, C.F.D. 2006a. Reptilia, Scincidae, Mabuya frenata: Distribution Extension. Check List 2(2):57-58.

VRCIBRADIC, D., HATANO, F.H., ROCHA, C.F.D. \& VAN SLUYS, M. 2006b. Geographic Distribution. Phyllodytes luteolus. Herpetol. Rev. 37(4):489.

VRCIBRADIC, D., ALMEIDA-GOMES, M., SIQUEIRA, C.C., BORGES-JÚNIOR, V.N.T. \& ROCHA, C.F.D. $2011 \mathrm{a}$. Oxyrhopus petola digitalis (False Coral Snake). Prey. Herpetol. Rev. 42(2):299-300.

VRCIBRADIC, D., ROCHA, C.F.D., KIEFER, M.C., HATANO, F.H., FONTES, A.F., ALMEIDA-GOMES, M., SIQUEIRA, C.C., PONTES, J.A.L., BORGES-JÚNIOR, V.N.T., GIL, L.O., KLAION, T., RUBIÃO, E.C.N. \& VAN SLUYS M.,. 2011 b. Herpetofauna, Estação Ecológica Estadual do Paraíso, state of Rio de Janeiro, southeastern Brazil. Check List 7(6):745-749.

WEBER, L.N., BILATE, M., PROCACI, L.S. \& SILVA, S.P. 2007. Amphibia, Anura, Hylodidae, Hylodes charadranaetes: Distribution extension and notes on advertisement calls. Check List 3(4):336-337.

WEBER, L.N., SILVA-SOARES, T. \& SALLES, R.O.L. 2009. Amphibia, Anura, Hylidae, Hypsiboas secedens: reassessment of type locality coordinates and distribution extension. Check List 5(2):218-221.

WEBER, L.N.,VERDADE, V.K., SALLES, R.O.L., FOUQUET, A. \& CARVALHO-E-SILVA, S.P. 2011. A new species of Cycloramphus Tschudi (Anura: Cycloramphidae) from the Parque Nacional da Serra dos Órgãos, Southeastern Brazil. Zootaxa 2737:19-33.

WHILES, M.R., LIPS, K.R., PRINGLE, C.M., KILHAM S.S., BIXBY, R.J., BRENES, R., CONNELLY, S., COLON-GAUD, J.C., HUNT-BROWN, M., HURYN, A.D., MONTGOMERY, C. \& PETERSON, S. 2006. The effects of amphibian population declines on the structure and function of Neotropical stream ecosystems. Front. Ecol. Environ. 4(1):27-37. http://dx.doi.org/ 10.1890/1540-9295(2006)004[0027:TEOAPD]2.0.CO;2 


\section{Appendix 1}

\section{Voucher specimens of amphibians and reptiles from the Reserva Ecológica de Guapiaçu deposited at the Museu Nacional, Rio de Janeiro (MNRJ).}

AMPHIBIANS: GymnophionA: Siphonopidae: Siphonops hardyi (MNRJ 65728); Typhlonectidae: Chthonerpeton braestrupi (MNRJ 70119); ANURA: Brachycephalidae: Brachycephalus didactylus (MNRJ 55473-74, 57736, 68818-21, 86330); Brachycephalus ephippium (MNRJ 38104, 56517-18); Ischnocnema guentheri (MNRJ 53764, 55471-72, 59158, 66774-87, 68704, 86746-49); Ischnocnema octavioi (MNRJ 38129-32, 56613, 62328, 86767-68); Ischnocnema parva (MNRJ 56603, 66769-73, 73201-02); Ischnocnema cf. venancioi (MNRJ 60163); Bufonidae: Dendrophryniscus brevipollicatus (MNRJ 58294-95, 60701-02); Rhinella hoogmoedi (MNRJ 79893); Rhinella icterica (MNRJ 54372-74, 86314-16); Rhinella ornata (MNRJ 61075-91, 86737-43); Craugastoridae: Euparkerella brasiliensis (MNRJ 37317-18, 38212-21, 49300, 56932-35, 56943-51, 57561-63, 57735, 57737-41, 57787-90, 68702-3, 86845-47); Haddadus binotatus (MNRJ 53620, 55476-78, 66160, 66767-68, 86729-36); Cycloramphidae: Cycloramphus brasiliensis (MNRJ 55468, 76433-38); Thoropa miliaris (MNRJ 55447, 86710); Zachaenus parvulus (MNRJ 55448, 56938-39); Hemiphractidae: Fritziana goeldii (MNRJ 51516, 53758, 67315); Gastrotheca albolineata (MNRJ 59537, 65495, 86336); Hylidae: Aplastodiscus eugenioi (MNRJ 45783, 58950, 60197-98); Bokermannohyla circumdata (MNRJ 57018-22, 57292, 59536); Dendropsophus anceps (MNRJ 86317, 86722-25); Dendropsophus berthalutzae (MNRJ 79895, 86812-16); Dendropsophus bipunctatus (MNRJ 56936-37, 86804-07); Dendropsophus decipiens (MNRJ 67307); Dendropsophus elegans (MNRJ 49307, 86744-45); Dendropsophus giesleri (MNRJ 64156); Dendropsophus meridianus (MNRJ 63949, 86809-11); Dendropsophus microps (MNRJ 61050); Dendropsophus minutus (MNRJ 56940-41, 86801-03); Dendropsophus pseudomeridianus (MNRJ 86817-23); Dendropsophus seniculus (MNRJ 63947, 86726-28); Hypsiboas albomarginatus (MNRJ 86808); Hypsiboas albopunctatus (MNRJ 86896); Hypsiboas faber (MNRJ 86685-92); Hypsiboas pardalis (MNRJ 40610-11); Hypsiboas secedens (MNRJ 40609, 61475-77, 86331-34, 86337); Hypsiboas semilineatus (MNRJ 54013, 86339, 86750); Itapotihyla langsdorffii (MNRJ 86770-71); Phyllomedusa burmeisteri (MNRJ 47954, 68866, 86711-13); Phyllomedusa rohdei (MNRJ 64632; 86714-17); Scinax albicans (MNRJ 40080-82, 57243-44, 86751-66); Scinax alter (MNRJ 57084, 86782); Scinax argyreornatus (MNRJ 49514-25, 64634, 68692, 86783-90); Scinax cuspidatus (MNRJ 67397-98); Scinax flavoguttatus (MNRJ 53311); Scinax hayii (MNRJ 57600-02); Scinax humilis (MNRJ 40083-95, 49278-79, 58951, 61213, 63948); Scinax v-signatus (MNRJ 51800, 53902-03, 68691); Scinax aff. x-signatus (MNRJ 40809-11, 57783-86, 63950, 86318);Sphaenorhynchus planicola (MNRJ 87098-101); Trachycephalus mesophaeus (MNRJ 49301, 79894); Trachycephalus nigromaculatus (MNRJ 86709); Hylodidae: Crossodactylus aeneus (MNRJ 75172, 82563, 86838-41); Hylodes asper (MNRJ 60169-70, 60181, 86892); Hylodes charadranaetes (MNRJ 59064-65, 60167-68, 60174-77, 60180); Hylodes lateristrigatus (MNRJ 68986); Hylodes pipilans (MNRJ 59038-46, 59066, 60173, 68735); Megaelosia goeldii (MNRJ 86296); Leptodactylidae: Adenomera cf. bokermanni (MNRJ 86893); Adenomera marmorata (MNRJ 66561, 86327-29, 86772-81); Leptodactylus fuscus (MNRJ 86718); Leptodactylus latrans (MNRJ 51742-46, 61217); Leptodactylus mystacinus (MNRJ 86720-21); Leptodactylus spixi (MNRJ 57294, 86719); Physalaemus signifer (MNRJ 59897, 66441, 86791-800); Microhylidae: Chiasmocleis carvalhoi (MNRJ 38105-07, 49302, 53464, 68736, 68739-40, 74592, 86335); Myersiella microps (MNRJ 49311, 86837); Stereocyclops parkeri (MNRJ 54768, 57295, 60553, 86338); Odontophrynidae: Proceratophrys appendiculata (MNRJ 54012, 55470); Proceratophrys boiei (MNRJ 55469, 6876483, 68810-11, 86769); Ranidae: Lithobates catesbeianus (MNRJ 86693-94). REPTILES: SQUAMATA: Amphisbaenidae: Amphisbaena microcephala (MNRJ 16474); Anguidae: Ophiodes striatus (MNRJ 19410); Boidae: Corallus hortulanus (MNRJ 18550, 19231); Colubridae: Chironius bicarinatus (MNRJ 18066); Chironius foveatus (MNRJ 15375, 18479); Chironius fuscus (MNRJ 16909, 19743, 24134); Echinanthera amoena (MNRJ 18068); Echinanthera cephalostriata (MNRJ 12347, 19288); Helicops carinicaudus (MNRJ 18085); Imantodes cenchoa (MNRJ 19289, 23207); Liophis miliaris (MNRJ 18528, 24389); Liophis reginae (MNRJ 16364, 18462); Oxyrhopus clathratus (MNRJ 23509); Oxyrhopus petolarius (MNRJ 12349, 15370, 18211); Philodryas patagoniensis (MNRJ 1235051, 16365); Sibynomorphus neuwiedi (MNRJ 12345-46, 18086); Siphlophis compressus (MNRJ 19389); Taeniophallus affinis (MNRJ 16899, 19165-66); Xenodon neuwiedii (MNRJ 16367, 18097, 19388); Dactyloidae: Anolis fuscoauratus (MNRJ 16548); Anolis punctatus (MNRJ 15373, 19133, 19245-46); Elapidae: Micrurus corallinus (MNRJ 24391); Gekkonidae: Hemidactylus mabouia (MNRJ 12353, 19243-44); Gymnophtalmidae: Ecpleopus gaudichaudi (MNRJ 12352, 24276-300); Leiosauridae: Enyalius brasiliensis (MNRJ 12354-58, 21569-82); Phyllodactylidae: Gymnodactylus darwini (MNRJ 20558-72); Scincidae: Mabuya macrorhyncha (MNRJ 19241-42); Viperidae: Bothrops jararaca (MNRJ 16366); Bothrops jararacussu (MNRJ 12348); TESTUDINES: Chelidae: Hydromedusa maximiliani (MNRJ 21127). 